\title{
Türk Bankacılık Sektörünün Aktif Yapısındaki Değişim ve Gelişimler*
}

\section{Changes and Developments in Asset Structure of Turkish Banking Sector}

\author{
Öğr. Gör. Hakan SARIKALE ${ }^{1}$, Prof. Dr. Cantürk KAYAHAN ${ }^{2}$
}

\begin{abstract}
Özet
Bu çalışmada; Türkiye'de faaliyet gösteren mevduat, kalkınma ve yatırım bankası bilançolarının aktifinde yer alan varlıkların, 2002-2016 yılları arasında bilanço içerisindeki yüzdesel değişimi ve bu değişimin nedenlerinin incelenmesi hedeflenmiştir. İlgili dönemi kapsayan inceleme sonucunda Türk Bankacılık sektörünün menkul kıymet ağılıklı banka bilançolarından, kredi ağılıklı bilançolara geçiş sağladığı görülmüştür. Banka bilançolarının aktifinde yer alan "likit aktif, finansal varlık, kredi, duran aktif ve diğer aktif" hesap gruplarının toplam aktif içerisindeki paylarında meydana gelen değişimler yüzde analizi yöntemiyle incelenmiştir. Değișimin nedenleri araştırıldıktan sonra, devlet borçlanması ile reel sektör ve banka bilanço yapısı arasında nasıl bir etkileşim olduğunu anlayabilmek amacıyla korelasyon analizi yapılmıştır. 2002-2016 yılları arasında; "Kamu Net Borç Stoku/GSYH" oranının değişimi, özel sektör bilançolarındaki "banka kredileri/yabancı kaynak" oranının değişimi ile banka bilançolarındaki "Kredi/Aktif" ve "Finansal Varlık/Aktif" oranlarının değişimi arasındaki ilişki incelenmiş ve aralarında çok güçlü bir korelasyon olduğu tespit edilmiştir. Dolayısıyla bankaların risksiz kamu kağıtlarını alıp satmak yerine, gerçek işlevleri olan reel sektörün finansman ihtiyacını karşılar duruma geldikleri belirtilebilir.
\end{abstract}

Anahtar Kelimeler: Banka, bilanço, aktif, kredi, menkul kıymet

Makale Türü: Araştırma makalesi

\begin{abstract}
In this study it is aimed to investigate the percentage change and reasons of deposit, development and investment banks' assets in their balance sheet within the period of 2002-2016 in Turkey. According to the analysis of related period it is observed that Turkish banking sector has shifted toward credit weighted balance sheets rather than deposit weighted. Liquid assets, financial assets, credit, fixed assets and other assets account groups which are placed in total assets and existing changes are examined through percentage analysis method. After the investigation of the reason of changes, correlation analysis is made in order to understand the interaction between public debts with real sector and bank balance sheet structures. In this scope the relationship between changes in "public net debt stock/GDP", changes in private sector "bank credits/liabilities" and changes in "credit/assets" and "financial assets/assets" of the bank balance sheets are examined. Then positive and strong relationship is found. Consequently banks
\end{abstract}

\footnotetext{
* Bu çalışma Mayıs 2018'de Başkent Üniversitesi ev sahipliğinde yapılan 1. Uluslararası Bankacılık Kongresinde sunulmuş ve genişletilmiş özet olarak yayınlanmıştır.

${ }^{1}$ Muğla Sitk1 Koçman Üniversitesi, Ula Ali Koçman MYO, hakansarikale@mu.edu.tr, Orcid ID: https://orcid.org0000-0003-1682-3338

${ }^{2}$ Afyon Kocatepe Üniversitesi , Bolvadin Uygulamalı Bilimler Yüksekokulu, ckayahan@aku.edu.tr, Orcid ID: https://orcid.org0000-0003-4777-1470
} 
become financier of real sector demands as their core business rather than buying-selling of the risk free public bonds.

Keywords: Bank, balance sheet, asset, credit, securities

Paper Type: Research paper

\section{Giriş}

Bankacılık sektörü günümüz dünyasının en dinamik finans kurumlarının başında gelmektedir. Bankaların hizmet alanları her geçen gün çeşitlenmekte kurumsal ve bireysel yatırımcılar tarafindan da dikkatle izlenmektedir. Özellikle günümüz bankacılık endüstrisi küresel bir görünüm sergilemekte ve uluslararası bankacılık alanına yönelik farkındalık artmaktadır. Buna karşın BIS (2018) tarafından yayınlanan raporlarda özellikle son yaşanan kriz öncesinde küresel bankacılık sektörünün dünya ekonomik aktivitesinden ve ticaretinden çok daha hızlı bir gelişim gösterdiği; kriz sonrası ise yabancı banka varlıklarının düşme eğilimi sergilediği vurgulanmaktadır. Dolayısıyla bu durum, bankaların varlık ve borç yapısındaki değişimlerin temel nedenlerinden birisini oluşturmaktadır.

Bankalar, öz kaynak ve yabancı kaynak yoluyla topladıkları fonları, plasman yoluyla fon talep edenlere kullandırmak suretiyle kazanç sağlamaktadır (Aslanoğlu, 2013: 73). Kaynaklar banka bilançolarının pasifinde, bu kaynakların kullanım yerleri ise aktifinde yer almaktadır. Sektördeki banka bilançoları incelendiğinde krediler ile finansal varlıkların, aktifler içerisinde en büyük paya sahip olduğu görülmekte olup, bazı dönemlerde finansal varlıkların, bazı dönemlerde de kredilerin bilançodaki ağırlığı artmaktadır. $\mathrm{Bu}$ çalışmada banka kaynaklarının kullanım yerlerinde yani banka bilançolarının aktifinde, 2002-2016 yılları arasında meydana gelen yapısal değişim ve bu değişimin nedenleri incelenmektedir.

Kamu kesimi iç borçlanma yoluyla ticari bankalar, merkez bankası ve özel kişi/kurumlardan kaynak sağlayabilmektedir. Bununla birlikte tasarruf düzeyi düşük olan gelişmekte olan ülkelerde ticari bankalar en önemli iç borç kaynağıdır (Demir ve Sever, 2008:173). Kaynakların kamu ile özel sektör arasındaki paylaşımının bankacılık krizlerinde önemli bir etkisi vardır. Tasarruf yetersizliği olan ülkelerde finansal sistemdeki kaynaklar yüksek reel faiz ile kamu açıklarının kapatılması için kamu kesimine aktarılmaktadır (Sönmezler, 2008:1). Banka bilançolarında; kamu borçlanma araçları finansal varlıklar grubunda, reel sektöre sağlanan plasmanlar ise krediler grubunda yer almaktadır.

Türkiye'de bankacılık sektörü 2001 krizi sonrasında yeniden yapılandırma sürecine girmiştir. Kriz sonrası sektördeki banka sayısı azalmış, bankacılık mevzuatı değiştirilmiş, özellikle BDDK'nın yapmış olduğu düzenleme ve denetimler ile bankalar finansal açıdan daha homojen bir hale gelmiştir (Tükenmez ve Özdemir, 2017: 1127). Bu nedenle çalışmanın başlangıç yılı 2002 olarak belirlenmiş ve 15 yıllık süreçte aktif yapıda meydana gelen dönüşüm incelenmiştir.

\section{Literatür Taraması}

Aydın (2002), 1990'lı yıllardan sonra artan kamu iç borçlanmasının 2001 yılına kadar banka bilançolarında meydana getirdiği dönüşümü incelemiştir. Bu çalışmada kamu borçlanma araçlarının en büyük alıcısı olan bankaların, özellikle 1990'lı yıllardan sonra reel sektörü fonlamak yerine kamuyu fonladıkları ve bu nedenle bilanço yapılarının menkul kıymet lehine değiştiği belirtilmiştir. Bunun gerekçesi olarak ise; kredi riski ve kaynak maliyetinin artması ile kamu borçlanma araçlarının daha az riskli ve yüksek reel faizli olması gösterilmiştir. 
Blaško ve Sinkey (2006), 1989-1996 yılları kapsayan çalışmalarında ABD bankalarının varlık yapısı, gayrimenkul kredileri ve risk tercihlerini incelemişler; gayrimenkul kredilerinde önemli bir artış olduğunu, kaynakların büyük kısmının değişken faizle fonlanmasına karşın sabit faizli kredilerin toplam varlıklar içerisindeki payının daha yüksek olduğunu ve bunun da faiz oranları aşırı bir şekilde arttığında bankalar üzerindeki riskleri artıracağını ifade etmişlerdir.

Sönmezler (2008), 2001 krizinden önceki dönemde kamu açıklarının finansmanı ile bankaların yurtdışı yükümlülükleri arasındaki ilişkiyi incelemiştir. 1997-1999 yılları arasını kapsayan çalışmada bütçe açıklarının, iç borç faizi ve bankaların yurtdışı yükümlülüklerini artırdığını belirtmiştir. Bu durumun ise bankaları krizlere karşı daha da kırılganlaştırdığını ifade ederek, mali baskınlığın azaltılması gerektiğini savunmuştur.

Foos, Norden ve Weber (2010), 1997-2007 yıllarını kapsayan çalışmalarında; aşırı kredi büyümesi ile bankaların risklilik düzeyleri arasındaki ilişkiyi incelemişler ve anormal kredi büyümesinin takipteki kredileri artırdığı, banka karlılığını azalttığı ve dolayısıyla varlık riski ile sermaye yeterlik rasyosu üzerinde olumsuz etkiler oluşturduğu sonucuna ulaşmışlardır.

Özdemir (2005), bankacılık tarihi ve bilanço büyüklüklerini değerlendirdiği çalışmasında; Türkiye'deki bankacılık krizlerinin nedeninin yapısal sorunlar olduğunu ve kamu kesiminin etkinliğinin azalması ile birlikte daha rekabetçi bir sektör yapısının oluşacağını belirtmiştir.

Selvigül (2012), bankacılık sistemindeki yapısal sorunların ve bankaların ağırlıklı olarak kamuyu finanse etmesinin reel sektör üzerindeki olumsuz etkisinin 2001 krizi sonrasında farkına varıldığını ifade etmiştir. Bu çalışmada; Güçlü Ekonomiye Geçiş Programı sonrasında yapılan yapısal düzenlemeler sonucunda, 2001-2010 yılları arasında banka bilançolarının aktifpasif dağılımlarında önemli değişimler olduğu, kamu, özel ve yabancı sermayeli bankalar arasında daha homojen bir yapıya ulaşıldığı, aktif içerisinde kredilerin ağırlığının arttığı ancak kredi vadelerinin mevduat vadeleriyle uyumsuz olduğu, bununla birlikte bankaların aktif kalitesinin artmakta olduğu belirtilmektedir.

Poyraz (2012), bankaların 1960-2010 yılları arasındaki kredi/aktif oranı ile özkaynak ve aktif karlılıkları arasındaki korelasyon ve regresyon analizlerini yapmış ve optimum kredi düzeyini belirlemeye çalışmışır. Kredi/aktif oranı ile karlılık oranları arasında zayıf da olsa, bir korelasyon olduğu sonucuna ulaşmıştır.

Babuşcu ve Hazar (2013), 2003-2006 yılları ile 2007-2011 yılları arasını iki ayrı döneme ayırarak 5411 Sayılı Bankacılık Kanunu ile diğer düzenlemelerin bankaların finansal tabloları üzerinde etkilerinin olup olmadığını araştırmış ve yasal düzenlemelerin finansal yapıyı etkilediği sonucuna ulaşmıştır.

Mengüç (2017), Türkiye'deki bankaların yapısal değişimini incelediği çalışmasında, son 20 yılda bankaların asli görevlerinin (reel sektör finansmanının) dışına çıktıklarını, reel sektör yerine hane halkı kredilerine yöneldiklerini ve karlarını komisyon ve bilanço dışı kalemlerle artırmaya çalıştıklarını belirtmektedir.

\subsection{Banka Türleri}

Bankacılık Kanununda banka türleri üçe ayrılmış ve şu şekilde tanımlanmıştır (5411 Sayılı Bankacilık Kanunu, 2005); 
Mevduat bankası: Kendi nam ve hesabına mevduat kabul eden ve kredi kullandırımı esas olmak üzere faaliyet gösteren bankalardır.

> Katılım bankası: Özel cari ve katılma hesapları yoluyla fon toplayan ve kredi kullandırımı esas olmak üzere faaliyet gösteren bankalardır.

> Kalkınma ve yatırım bankası: Mevduat veya katılım fonu kabul etme dışında; kredi kullandırımı esas olmak üzere faaliyet gösteren ve/veya özel kanunlarla kendilerine verilen görevleri yerine getiren bankalardır.

\subsection{Banka Bilançosunun Yapısı ve Banka Aktiflerine İlişkin Verilerin Raporlanması}

Bankaların faaliyetleri ve nitelikleri gereği, muhasebe süreçleri ile raporlamaları diğer şirketlerden farklıdır. Dolayısıyla kullanılan hesaplar için de farklı bir tekdüzen hesap planı kullanılır. Türkiye'de faaliyet gösteren mevduat bankaları ile kalkınma ve yatırım bankaları “Tekdüzen Hesap Planı ve İzahnamesi Hakkında Tebliğ" hükümlerine (BDDK, 2007a), katılım bankaları ise "Katılım Bankalarınca Uygulanacak TDHP ve İzahnamesi Tebliği" hükümlerine (BDDK, 2007b) tâbidir. Buna göre mevduat bankaları ile kalkınma ve yatırım bankaları bilançolarında yer alan gruplar şu şekildedir;

\section{Aktif:}

0 - Dönen Değerler

1 - Krediler

2 - Yatırım Amaçlı Değerler ve Diğer Aktifler

\section{Pasif:}

3 - Mevduat ve Diğer Yabancı Kaynaklar

4 - Özkaynaklar

Bankalara ilişkin verilere; Türkiye Bankalar Birliği (TBB), Bankacılık Düzenleme ve Denetleme Kurumu (BDDK), Merkez Bankası (TCMB) ile ilgili bankaların faaliyet raporlarından ulaşılabilmektedir. $\mathrm{Bu}$ raporlar incelendiğinde bankaların aktif yapısı ile ilgili raporlamaların tek düzen hesap planında yer alan üçlü sınıflandırmadan farklı şekillerde yapıldığı görülmektedir. Buna göre bankaların aktif yapısıyla ilgili raporlama türleri dört grupta siniflandirılabilir:

1) Kazanç sağlama durumuna göre:

$>$ Getirili Aktif

$>$ Getirisiz Aktif

2) Para birimine göre:

$>$ Türk Lirası Aktif

$>$ Yabanc1 Para Aktif

3) Risk durumuna göre:

> Riskli Varlık 


\section{$>$ Risksiz Varlik}

\section{4) Hesap gruplarına göre ${ }^{3}$ :}

$\begin{array}{ll}> & \text { Likit Aktifler } \\ > & \text { Finansal Varlıklar } \\ > & \text { Krediler ve Alacaklar } \\ > & \text { Duran Aktifler } \\ > & \text { Diğer Aktifler }\end{array}$

Türkiye Bankalar Birliği’nin yapmış olduğu raporlamalarda; nakit değerler, TCMB, bankalar ve para piyasasından alacaklar likit aktifler içerisinde yer alırken, iştirakler, bağlı ortaklıklar, maddi ve maddi olmayan duran varlıklar, satış amacıyla elde tutulan ve durdurulan faaliyetlere ilişkin duran varlıklar ile net takipteki krediler ise duran aktifler içerisinde yer almaktadır. Finansal varlıklar ise; gerçeğe uygun değer farkı kar/zarara yansıtılan, satılmaya hazır, vadeye kadar elde tutulacak ve riskten korunma amaçlı türev finansal varlıklar şeklinde belirtilmektedir. (TBB, 2017a).

Grafik 1: Banka bilançolarındaki hesap gruplarının dağılımı
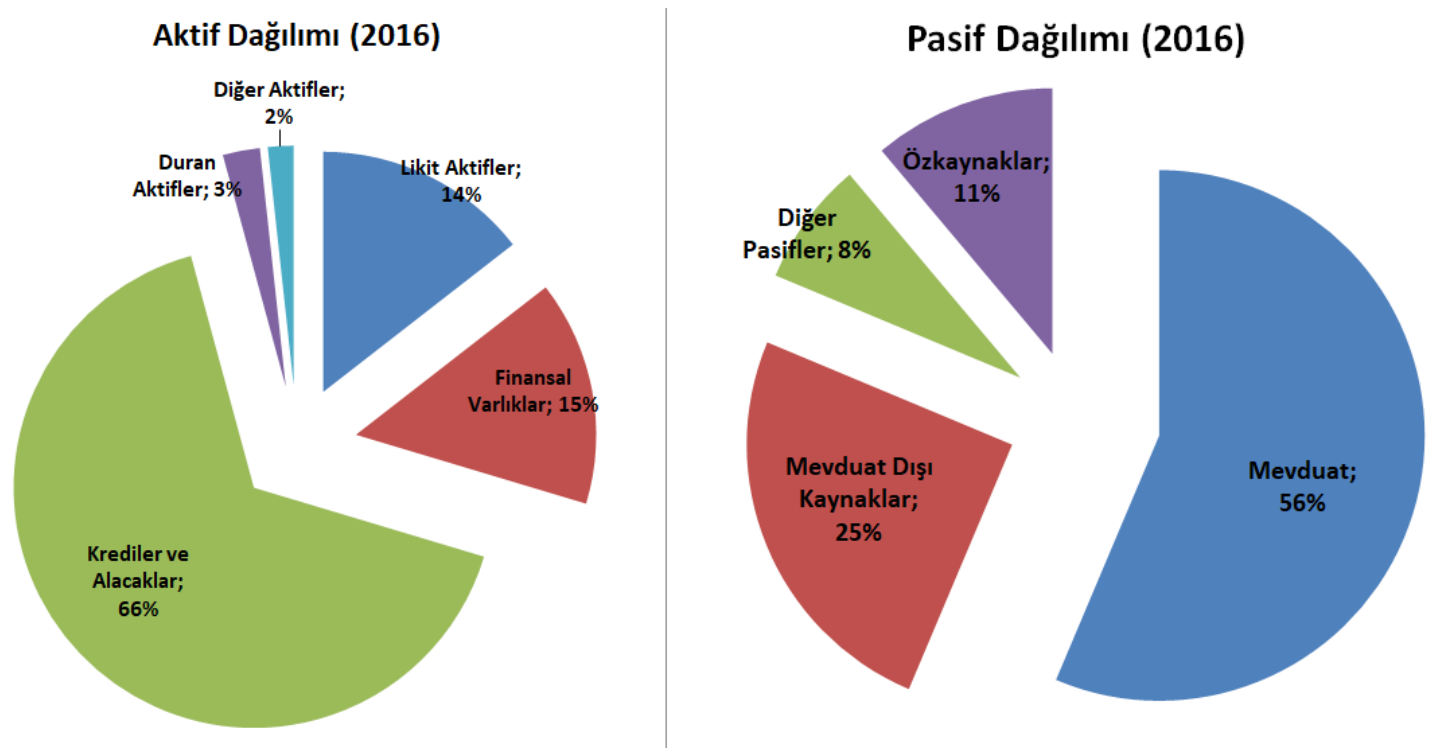

Grafik, Türkiye Bankalar Birliğinden alınan veriler kullanılarak oluşturulmuştur.

Grafik 1'den de görüleceği üzere 2016 yılsonu itibarılla banka bilançolarının aktifinin \%66'sını krediler ve alacaklar oluşturmakta iken, \%15'ini finansal varlıklar oluşturmaktadır. Pasife bakıldığında ise, mevduatların pasif içerisindeki payı \%56 iken, mevduat dışı kaynakların payı \%25, Özkaynakların payı ise \%11'dir. Buna göre bankalar ağırlıklı olarak mevduat toplama yoluyla kaynak sağlamakta ve bu kaynakların büyük çoğunluğunu kredi vererek değerlendirmektedir. 2016 sonu itibarıyla durum bu şekilde olmakla birlikte, banka bilançolarının yıllar itibarıyla nasıl bir dönüşüm gösterdiğini anlayabilmek amacıyla bu yüzdelerin 15 yıllık süre içerisindeki değişimi incelenmiştir. Tablo 1'de; mevduat, kalkınma ve yatırım bankalarının aktifinde yer alan hesapların yılsonu bakiyeleri gösterilmektedir.

\footnotetext{
3 Bu çalışmada yapılan analizlerde Türkiye Bankalar Birliği’nin (TBB) hesap gruplarına göre yaptı̆̆ raporlama verileri kullanılmıştır.
} 
Tablo 1. 2002-2016 yılları bankacılık sektörü aktif hesaplarına ilişkin veriler (bin TL)

\begin{tabular}{|l|l|l|l|l|l|l|}
\hline Y1llar & $\begin{array}{l}\text { Likit } \\
\text { Aktifler }\end{array}$ & $\begin{array}{l}\text { Finansal } \\
\text { Varlıklar }\end{array}$ & $\begin{array}{l}\text { Krediler } \\
\text { Alacaklar }\end{array}$ & $\begin{array}{l}\text { Duran } \\
\text { Aktifler }\end{array}$ & $\begin{array}{l}\text { Diğer } \\
\text { Aktifler }\end{array}$ & $\begin{array}{l}\text { Toplam } \\
\text { Aktifler }\end{array}$ \\
\hline $\mathbf{2 0 0 2}$ & 34.357 .179 & 86.111 .794 & 56.370 .271 & 18.254 .122 & 17.582 .122 & $\mathbf{2 1 2 . 6 7 5 . 4 8 8}$ \\
\hline $\mathbf{2 0 0 3}$ & 36.293 .284 & 106.910 .244 & 69.990 .148 & 19.349 .013 & 17.207 .084 & $\mathbf{2 4 9 . 7 4 9 . 7 7 3}$ \\
\hline $\mathbf{2 0 0 4}$ & 43.019 .560 & 123.680 .144 & 103.241 .145 & 22.140 .694 & 14.370 .022 & $\mathbf{3 0 6 . 4 5 1 . 5 6 5}$ \\
\hline $\mathbf{2 0 0 5}$ & 63.204 .710 & 143.016 .089 & 153.059 .052 & 20.129 .288 & 17.560 .920 & $\mathbf{3 9 6 . 9 7 0 . 0 5 9}$ \\
\hline $\mathbf{2 0 0 6}$ & 74.163 .563 & 168.274 .327 & 218.063 .925 & 17.250 .124 & 7.105 .323 & $\mathbf{4 8 4 . 8 5 7 . 2 6 2}$ \\
\hline $\mathbf{2 0 0 7}$ & 74.831 .585 & 175.856 .820 & 280.453 .091 & 19.214 .420 & 10.815 .963 & $\mathbf{5 6 1 . 1 7 1 . 8 7 9}$ \\
\hline $\mathbf{2 0 0 8}$ & 100.885 .955 & 207.806 .899 & 366.900 .914 & 19.696 .667 & 10.580 .339 & $\mathbf{7 0 5 . 8 7 0 . 7 7 4}$ \\
\hline $\mathbf{2 0 0 9}$ & 102.567 .401 & 280.929 .570 & 381.012 .568 & 22.464 .598 & 11.558 .541 & $\mathbf{7 9 8 . 5 3 2 . 6 7 8}$ \\
\hline $\mathbf{2 0 1 0}$ & 104.691 .182 & 308.992 .394 & 508.862 .117 & 24.973 .401 & 14.356 .678 & $\mathbf{9 6 1 . 8 7 5 . 7 7 2}$ \\
\hline $\mathbf{2 0 1 1}$ & 149.854 .867 & 303.367 .964 & 664.289 .489 & 26.488 .222 & 16.711 .254 & $\mathbf{1 . 1 6 0 . 7 1 1 . 7 9 6}$ \\
\hline $\mathbf{2 0 1 2}$ & 182.199 .163 & 294.198 .229 & 768.939 .362 & 32.356 .608 & 20.449 .165 & $\mathbf{1 . 2 9 8 . 1 4 2 . 5 2 7}$ \\
\hline $\mathbf{2 0 1 3}$ & 251.999 .759 & 307.977 .599 & 1.015 .524 .202 & 34.738 .826 & 25.129 .691 & $\mathbf{1 . 6 3 5 . 3 7 0 . 0 7 7}$ \\
\hline $\mathbf{2 0 1 4}$ & 282.747 .569 & 326.393 .134 & 1.209 .686 .009 & 42.525 .839 & 26.955 .927 & $\mathbf{1 . 8 8 8 . 3 0 8 . 4 7 8}$ \\
\hline $\mathbf{2 0 1 5}$ & 326.584 .772 & 357.191 .360 & 1.458 .516 .466 & 56.850 .545 & 36.851 .571 & $\mathbf{2 . 2 3 5 . 9 9 4 . 7 1 4}$ \\
\hline $\mathbf{2 0 1 6}$ & 375.873 .066 & 393.247 .644 & 1.716 .622 .954 & 64.912 .480 & 44.691 .840 & $\mathbf{2 . 5 9 5 . 3 4 7 . 9 8 4}$ \\
\hline
\end{tabular}

Kaynak: TBB, $2017 b$.

Yıllar içerisindeki değişimi karşılaştırabilmek ve görsel olarak daha iyi ifade edebilmek amacıyla yukarıdaki tabloda verilen her bir hesap grubunun, toplam aktif içerisindeki yüzdesel payları hesaplanmış ve aşağıdaki grafik oluşturulmuştur.

Grafik 2. Bankacılık sektörünün aktif yapısındaki değişim (2002-2016)

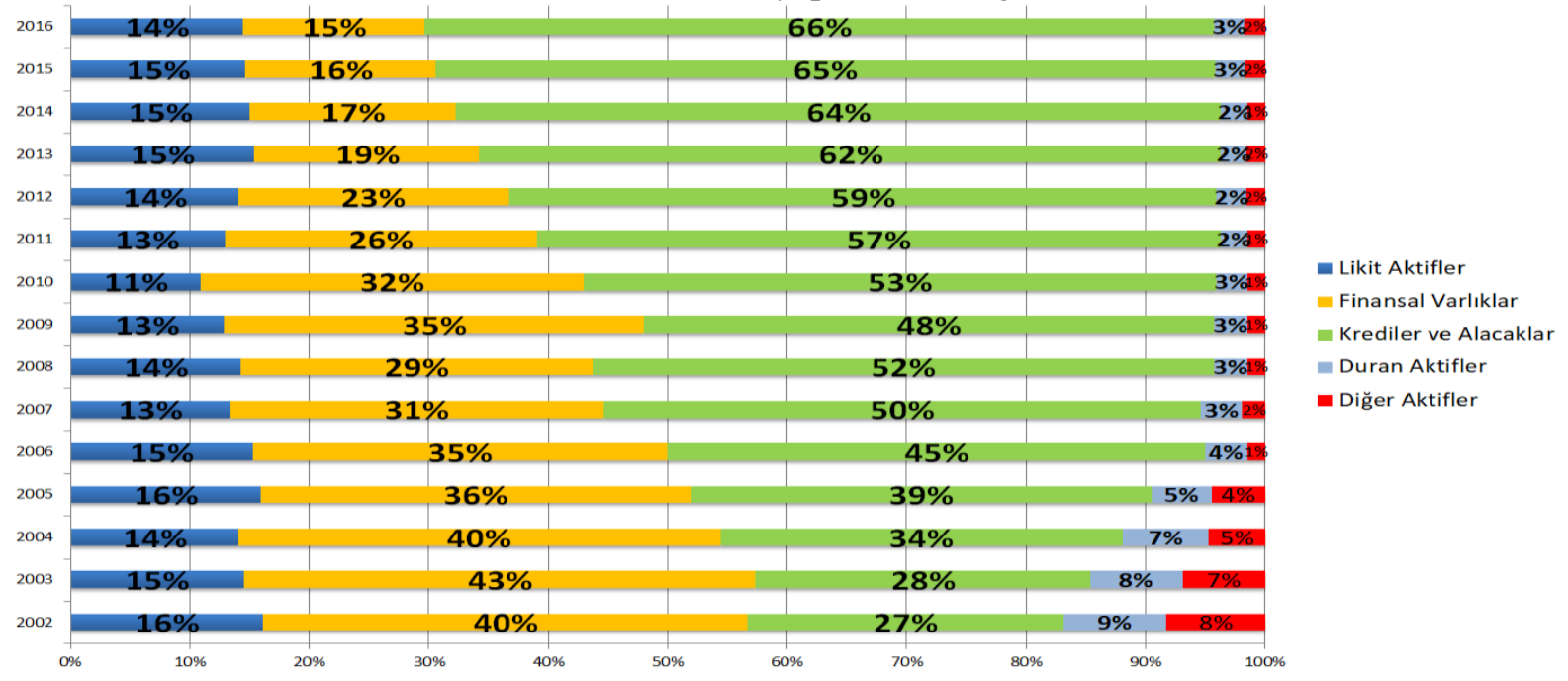

Grafik, Türkiye Bankalar Birliğinden alınan veriler kullanılarak oluşturulmuştur.

Kamu bankalarının sektörle karşılaştırılabilmesi amacıyla, kamu bankalarının aktifindeki hesapların yüzdesel payları da 3 nolu grafikte gösterilmiştir. 
Grafik 3. Kamu bankalarının aktif yapısındaki değişim (2002-2016)

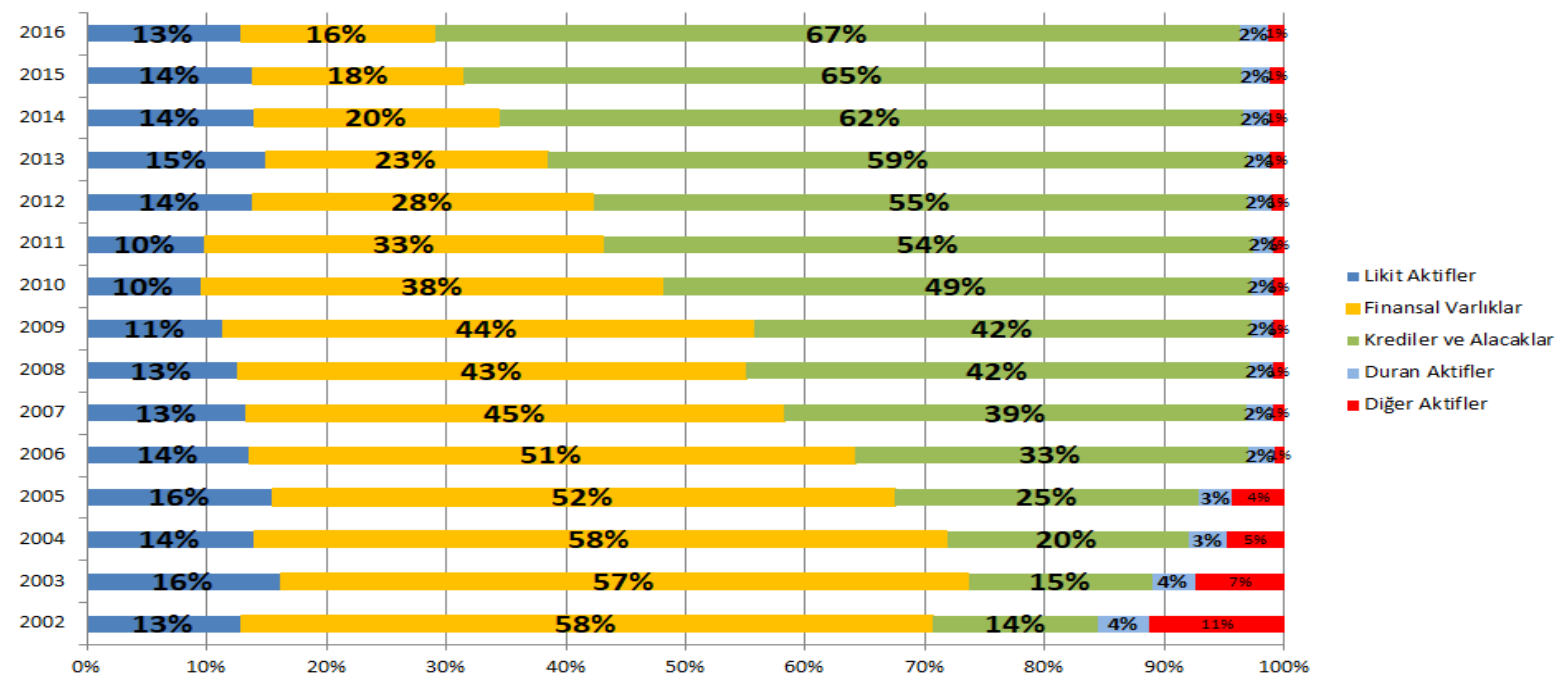

Grafik, Türkiye Bankalar Birliğinden alınan veriler kullanılarak oluşturulmuştur.

\subsection{Likit Aktif, Duran Aktif, Diğer Aktif Hesap Grupları}

Likit aktifler; temel olarak nakit değerler, bankalar ve TCMB nezdindeki hesaplar ile para piyasasındaki alacaklardan oluşmaktadır. Dolayısıyla bu hesap grubunda; günlük likidite ihtiyacının karşılanması ve faaliyetlerin yürütülmesi amacıyla tutulan varlıklar yer almaktadır. Aktif içerisindeki payına bakıldığında da 15 yıllık süre içerisinde ortalama olarak \%14 seviyesinde seyrettiği ve incelemeye değer bir dalgalanma göstermediği görülmektedir.

Benzer şekilde; likit aktif, finansal varlık, kredi ve duran aktif gruplarına dahil olmayan hesapların takip edildiği diğer aktifler hesap grubu da aktif içerisinde çok düşük bir yüzdeye sahip olduğundan inceleme dışında bırakılmıştır.

Duran aktifler ise temel olarak; iştirakler ve ortaklıklar ile maddi ve maddi olmayan duran varlıklardan oluşmaktadır. Bankacılık Kanununda, bankaların bir ortaklıkta sahip olabileceği paylar ile ilgili sınırlamalar mevcuttur. Benzer şekilde sahip olunan gayrimenkullerin net defter değerinin öz kaynaklarının yarısını aşamayacağı da belirtilmektedir. Dolayısıyla duran aktiflerin aktif içindeki payının belirli bir seviyenin üzerine çıkması, kanuni sınırlamalar nedeniyle de olası değildir. "Duran aktif/Aktif toplamı" oranına bakıldığında da 2002-2006 yılları arasında \%9'dan \%4'e düştügü, sonraki yıllarda da ortalama \%3 seviyesinde seyrettiği ve aşırı dalgalanma göstermediği görülmektedir.

Çalışmasının asıl konusunu oluşturan finansal varlıklar ve krediler gruplarında yaşanan değişimin nedenleri ise aşağıda detaylı olarak açıklanmıştır.

\subsection{Finansal Varlıklar ve Krediler Hesap Gruplarındaki Yüzdesel Değişimin Nedenleri}

2001 ve öncesindeki krizlerde devlet borçlanması ve bankacılık sektöründeki sıkıntılar başroldedir. Bankaların temel görevi reel sektöre fon sağlamaktır. Ancak kamu açıkları, sermaye yetersizliği ve yapısal sorunlar nedeniyle bankalar bu fonksiyonlarını tam olarak yerine getirememiştir. Kamu kağıtlarının yüksel reel kazanç sağlaması, bankaları sahip oldukları fonları reel sektöre kredi vermek yerine, devlete borç vermeye yöneltmiştir. Bu nedenle 
bankalar kamu açıklarının finansmanını sağlayan kurumlar haline gelmiştir (Seyidoğlu, 2003147).

Kamu kesiminin yüksek borç stoku, banka faaliyetlerini ve aktif yapısını etkilemekte olup; kamu borçlanma araçlarının ödenmeme riskinin düşük olması ve yüksek reel faiz, bankaların aktiflerinde bu varlıkları tutmasına yol açar. Bu durum da bankaların piyasaya sağlayacakları kaynakların sınırlandırılmasına ve kredi gibi esas faaliyetleri yerine bu tip menkul kıymet yatırımlarına yönelmelerine neden olur (Yiğitoğlu, 2005).

2001 krizi öncesinde, büyüyen kamu açıklarını finanse etmek için çıkarılan kamu kağıtları, bankaları risksiz kazanca yöneltmiş ve finansal varlık alımlarını artırmıştır (Özdemir, 2005).

2001-Şubat krizinden sonra, yeniden istikrarı sağlayabilmek amacıyla "Güçlü Ekonomiye Geçiş Programı" yürürlüğe konulmuştur. IMF'den ek kredi sağlanmış, bankacılık sektörünün yapılandırılması ve kamu maliyesinin sağlamlaştırılması için bir takım yasal değişiklikler yapılmıştır. Bankacılık Sektörünün yapılandırılması için yeni Bankacılık Kanunu hazırlanmış, TMSF'ye devredilen bankaların sermayeleri güçlendirilmiş, kamu bankalarının görev zararlarını karşılamak üzere piyasa faizi taşıyan devlet tahvilleri verilmiştir. Özel Bankaların da sermaye artırımları zorunlu hale getirilerek temettü ödemeleri ertelenmiştir (Seyidoğlu, 2003-150).

Güçlü Ekonomiye Geçiş Programı kapsamında 2001-2004 yılları arasında bankacılık sektörünün yapılandırılması için Hazine tarafından kamu bankaları ile TMSF'ye devredilen bankalara yoğun olarak devlet iç borçlanma senedi ihraç edilmiştir. Bu işlem amacına ulaşmış, ancak aynı zamanda merkezi yönetimin yükümlülüklerini de artırmıştır (Derya, 2015).

2002-2004 y1lları arasında bankaların aktifindeki finansal varlık yüzdesinin düşmeme nedeni yukarıda açıklanmıştır. 2004 yılından sonra ise menkul kıymetlerin aktif içerisindeki payı yıllar içerisinde azalma göstermektedir.

2001 krizi sonrasında bankacılık sisteminin yapılandırılması ve mali yapısının güçlendirilmesi nedeniyle, 2009 yılında küresel finansal krizin etkileri sektör açısından sınırlı kalmış ve nispeten kolay atlatılmıştır (Artar ve Sarıdoğan, 2012).

2009 yılında ekonominin küçülmesi nedeniyle kamu gelirleri azalmış ve alınan tedbirler nedeniyle de kamu harcamaları artmıştır. İç borç stoğu/GSYH oranının artması, kamunun finansal kaynaklar üzerindeki baskısını artırmıştır. Ekonomide sorun yaşanan dönemlerde tüzel kişilerin devlet iç borçlanma senetlerine ilgisi artmaktadır. Bu nedenle bankaların DİBS talebi de artmış ve aktif içerisindeki menkul kıymetler yüzde 6 oranında artmıştır. Ayrıca ekonominin küçülmesi nedeniyle kredi talebindeki azalma ve risk nedeniyle bankaların kredi verme iştahındaki azalma, kredi/aktif oranını bir önceki yıla göre \%4 oranında azaltmıştır. 2009 yılının ilk yarısındaki risk algısındaki artış nedeniyle yükseltilen likit aktif/aktif oranı, yılın diğer yarısında azalmaya başlamıştır (TBB, 2010).

2009 yılında Grafik 2'den de izlenebileceği gibi \% 35 olan bankacılık sektörünün Finansal Varlık/Aktif oranı, kamu borçlanma ihtiyacının azalmasıyla birlikte yıllar içerisinde sürekli azalarak 2016 sonu itibariyle \%15 seviyesine gelmiştir. Grafik 3'de ise kamu bankalarının bilançolarındaki menkul kıymet/kredi dönüşümü, yukarıda sayılan nedenlerden dolayı diğer bankalara göre yüzdesel olarak daha fazla bir gelişim göstermiştir. 
Sonuç olarak, 2002-2016 yılları arasındaki 15 yıllık dönemde devlet borçlanmasının milli gelire oranı azalmış ve bunun sonucunda menkul kıymet ağırlıklı bilanço yapısından kredi ağırlıklı bilanço yapısına geçiş sağlanmıştır. Dolayısıyla bankalar ellerindeki kaynakları ağırlıklı olarak menkul kıymet satın almak yerine reel sektörün finanse edilmesinde kullanmaya başlamışlardır. $\mathrm{Bu}$ durum bankaların risk ağırlıklı varlıklarını artırmakla birlikte, aktif kalitesinin iyileştirilmesi ve asıl işlevlerinin gerçekleştirilmesi açısından olumlu karşılanmaktadır.

\subsection{Kamu ve Özel Sektör Arasındaki Kaynak Paylaşımı ile Bankaların Aktif Yapısındaki Değişimin Korelasyonu:}

Devletin finansman ihtiyacının yüksek olduğu dönemlerde ihraç edilen devlet iç borçlanma senetleri, bankaların risksiz kazanç sağlayan bu menkul kıymet alımlarını artırmakta ve kaynaklarını reel sektörü kredilendirmek yerine menkul kıymet alımlarında kullanmalarına neden olmaktadır. Dolayısıyla devlet borçlanması ile bankaların aktif yapısı arasındaki ilişkinin analiz edilmesi gerekir.

Menkul kıymet alımlarını artmasıyla birlikte bankaların kredi olarak kullandırılabileceği kaynakların azalması, kredi verme iştahının azalması, faiz oranlarında meydana gelen artış gibi nedenlerle reel sektörün de finansman sorunları ortaya çıkmaktadır.

$\mathrm{Bu}$ nedenle çalışmamızda 2002-2016 tarihleri arasında aşağıda belirtilen rasyolarda meydana gelen değişimler korelasyon analizi ile incelenmiştir.

\section{Devlet borçlanmasında meydana gelen değişim (Kamu Net Borç Stoku/GSYH)}

> Özel sektör bilançolarındaki "banka kredileri/yabancı kaynak" oranı değişimi

> Banka bilançolarındaki "Kredi/Aktif" oranlarındaki değişim

> Banka bilançolarındaki "Finansal Varlık/Aktif" oranlarındaki değişim

\section{a.) Devlet borçlanmasında meydana gelen değişim}

Kamu Net Borç Stoku, belirli bir tarih itibarıyla devlet kontrolündeki kurumların, kamunun sahip olduğu varlık ve alacaklar düşüldükten sonra, kamu sektörü dışındaki kişilere ödemekle yükümlü olduğu borç miktarıdır (Derya, 2015).

Kamu Net Borç Stoku/GSYH ise, kamu kesimi borcunun milli gelir içerisindeki oranını göstermektedir ve Hazine Müsteşarlığı tarafından yayınlanmaktadır. Bu çalışmada 15 yıllık süre içerisinde devletin borçlanma eğilimindeki değişikliği görebilmek amacıyla Kamu Net Borç Stoku/GSYH oranından faydalanılmıştır. Tablodan da görüleceği üzere kamu borçlarının milli gelire oranı yıllar itibarıyla azalmıştır. 


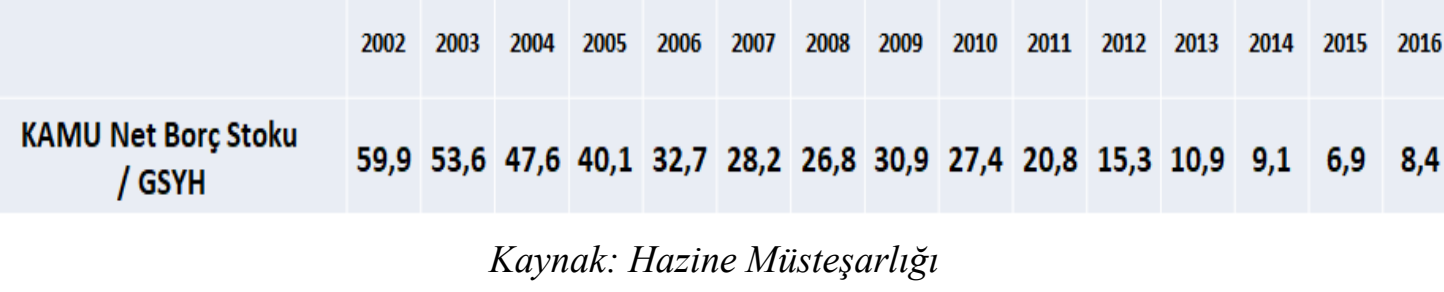

Kaynak: Hazine Müsteşarlı̆̆l

\section{b.) Özel sektör bilançolarındaki "banka kredileri/yabancı kaynak" oranı değişimi}

Sektör Bilançoları, Merkez Bankası tarafından kamuoyunu bilgilendirmek amacıyla, reel sektörde faaliyette bulunan firmaların finansal tablolarından elde edilen bilgilerin konsolide edilmesiyle oluşturulmaktadır. Bankacılık sisteminde kredisi olan veya TCMB veri tabanında verisi olan firmalara ait bilgiler, yıllar itibarıla konsolide edilip yayınlanmaktadır (TCMB,2017). Bu çalışmada, 15 yıllık süreçte firmaların yabancı kaynakları içerisindeki banka kredilerinde yüzdesel değişimi görebilmek için, Merkez Bankasının yayınlamış olduğu sektör bilançoları raporunda yer alan Banka Kredileri/Yabancı Kaynaklar Toplamı ${ }^{4}$ oranından faydalanılmıştır.

$\begin{array}{llllllllllllll}2002 & 2003 & 2004 & 2005 & 2006 & 2007 & 2008 & 2009 & 2010 & 2011 & 2012 & 2013 & 2014 & 2015\end{array}$

Banka Kredileri /

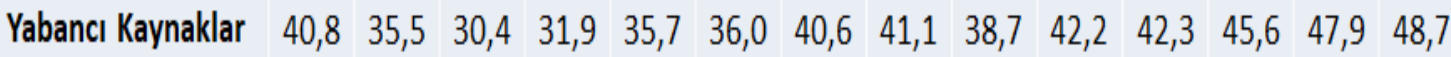
Toplamı Oranı

Kaynak: TCMB

c.) Banka bilançolarındaki "Kredi/Aktif" oranlarındaki değişim

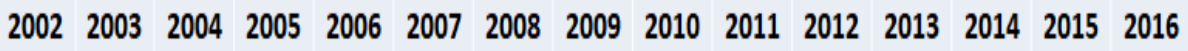

$\begin{array}{llllllllllllllll}\text { Kredi/Aktif (BANKA) } & 27 & 28 & 34 & 39 & 45 & 50 & 52 & 48 & 53 & 57 & 59 & 62 & 64 & 65 & 66\end{array}$

Kaynak: TBB

d.) Banka bilançolarındaki "Finansal Varlık/Aktif" oranlarındaki değişim

200220032004200520062007200820092010201120122013201420152016

$\begin{array}{llllllllllllllll}\text { Menkulkıvmet/Aktif (BANKA) } & 40 & 43 & 40 & 36 & 35 & 31 & 29 & 35 & 32 & 26 & 23 & 19 & 17 & 16 & 15\end{array}$

Kaynak: TBB

\footnotetext{
${ }^{4} 2016$ yılı verileri araştırma tarihi itibarıyla yayınlanmadığından bu rasyo için 2002-2015 verileri kullanılmıştır. 
Tablo 2. Korelasyon analizi sonuçları

\begin{tabular}{|c|c|c|c|c|c|}
\hline & & $\begin{array}{c}\text { Kredi/Aktif } \\
\text { (BANKA) }\end{array}$ & $\begin{array}{c}\text { Finansal } \\
\text { Varlık/Aktif } \\
\text { (BANKA) }\end{array}$ & $\begin{array}{c}\text { Kamu } \\
\text { Netborçstoku/GS } \\
\text { YH }\end{array}$ & $\begin{array}{c}\text { Banka kredileri / } \\
\text { Yabancı kaynak (REEL } \\
\text { SEKTÖR) }\end{array}$ \\
\hline $\begin{array}{l}\text { Kredi/Aktif } \\
\text { (BANKA) }\end{array}$ & $\begin{array}{l}\text { Pearson Correlation } \\
\text { Sig. (2-tailed) } \\
\mathrm{N}\end{array}$ & $\begin{array}{c}1 \\
15\end{array}$ & $\begin{array}{c}-0,954^{* *} \\
0,000 \\
15\end{array}$ & $\begin{array}{c}-0,995^{* *} \\
0,000 \\
15\end{array}$ & $\begin{array}{c}0,747^{* * *} \\
0,002 \\
14\end{array}$ \\
\hline $\begin{array}{c}\text { Finansal } \\
\text { Varlık/Aktif } \\
\text { (BANKA) }\end{array}$ & $\begin{array}{l}\text { Pearson Correlation } \\
\text { Sig. (2-tailed) } \\
\text { N }\end{array}$ & $\begin{array}{c}-0,954^{* *} \\
0,000 \\
15\end{array}$ & $\begin{array}{c}1 \\
15\end{array}$ & $\begin{array}{c}0,959^{* * *} \\
0,000 \\
15\end{array}$ & $\begin{array}{c}-0,833^{* *} \\
0,000 \\
14\end{array}$ \\
\hline $\begin{array}{c}\text { Kamu } \\
\text { Netborçstoku/GS } \\
\text { YH }\end{array}$ & $\begin{array}{l}\text { Pearson Correlation } \\
\text { Sig. (2-tailed) } \\
\text { N }\end{array}$ & $\begin{array}{c}-0,995^{* *} \\
0,000 \\
15\end{array}$ & $\begin{array}{c}0,959^{* * *} \\
0,000 \\
15\end{array}$ & $\begin{array}{c}1 \\
15\end{array}$ & $\begin{array}{c}-0,732^{\text {*** }} \\
0,003 \\
14\end{array}$ \\
\hline $\begin{array}{c}\text { Banka kredileri / } \\
\text { Yabancı kaynak } \\
\text { (REEL } \\
\text { SEKTÖR) }\end{array}$ & $\begin{array}{l}\text { Pearson Correlation } \\
\text { Sig. (2-tailed) } \\
\mathrm{N}\end{array}$ & $\begin{array}{c}0,747^{* *} \\
0,002 \\
14\end{array}$ & $\begin{array}{c}-0,833^{* *} \\
0,000 \\
14\end{array}$ & $\begin{array}{c}-0,732^{* *} \\
0,003 \\
14\end{array}$ & 14 \\
\hline
\end{tabular}

**. Korelasyon 0.01 düzeyinde anlamlıdır (2-tailed).

Pearson korelasyon katsayısı değeri -1 ile +1 arasında yer almaktadır. Korelasyon katsayısın $r=-1$ olması değişkenler arasında ters yönlü mükemmel bir ilişki bulunduğunu, $r=+1$ olması değişkenler arasında aynı yönlü mükemmel bir ilişki bulunduğunu, $r=0$ olması ise aralarında bir korelasyon bulunmadığını göstermektedir. Dolayısıyla katsayı bire yakınlaştıkça değişkenler arasındaki ilişki de güçlenmektedir (Schneider, 2010:46).

1) "Kredi/Aktif (BANKA)" ile "Finansal Varlık/Aktif (BANKA)" oranları arasında ters yönlü ve çok güçlü (\%95) bir ilişki vardır. (Bankaların aktifindeki menkul kıymet yüzdesi azaldıkça, kredi yüzdesi artmaktadır.)

2) "Kredi/Aktif (BANKA)" ile "Kamu Netborçstoku/GSYH" oranları arasında ters yönlü ve çok güçlü (\%99) bir ilişki vardır. (Kamu borç stoğu azaldıkça, Bankaların aktifindeki kredi yüzdesi artmaktadır.)

3) "Kredi/Aktif (BANKA)" ile "Reel sektör bilançolarındaki banka kredileri/yabancı kaynak" oranları arasında aynı yönlü ve güçlü (\%74) bir ilişki vardır. (Banka bilançolarındaki kredi/aktif oranı arttıkça, özel sektörün yabancı kaynakları içerisindeki banka kredisi payı da artmaktadır.)

4) "Kamu Netborçstoku/GSYH" ile "Reel sektördeki banka kredileri/Yabancı Kaynak" oranları arasında ters yönlü ve güçlü (\%73) bir ilişki vardır. (Kamu borç stoğu azaldıkça, özel sektörün yabancı kaynakları içerisindeki banka kredisi payı artmaktadır.)

5) "Finansal Varlık/Aktif (BANKA)" ile "Kamu Netborçstoku/GSYH" oranları arasında aynı yönlü ve çok güçlü (\%95) bir ilişki vardır. (Kamu borç stoğu azaldıkça, bankaların aktifindeki menkul kıymet yüzdesi de azalmaktadır.)

6) "Finansal Varlık/Aktif (BANKA)" ile "Reel sektördeki banka kredileri/Yabanc1 Kaynak" oranları arasında ters yönlü ve güçlü (\%83) bir ilişki vardır. (Bankaların aktifinde menkul kıymet yüzdesi arttıkça, özel sektörün yabancı kaynakları içerisindeki banka kredisi payı azalmaktadır.) 
Grafik 4. Rasyoların grafiksel gösterimi

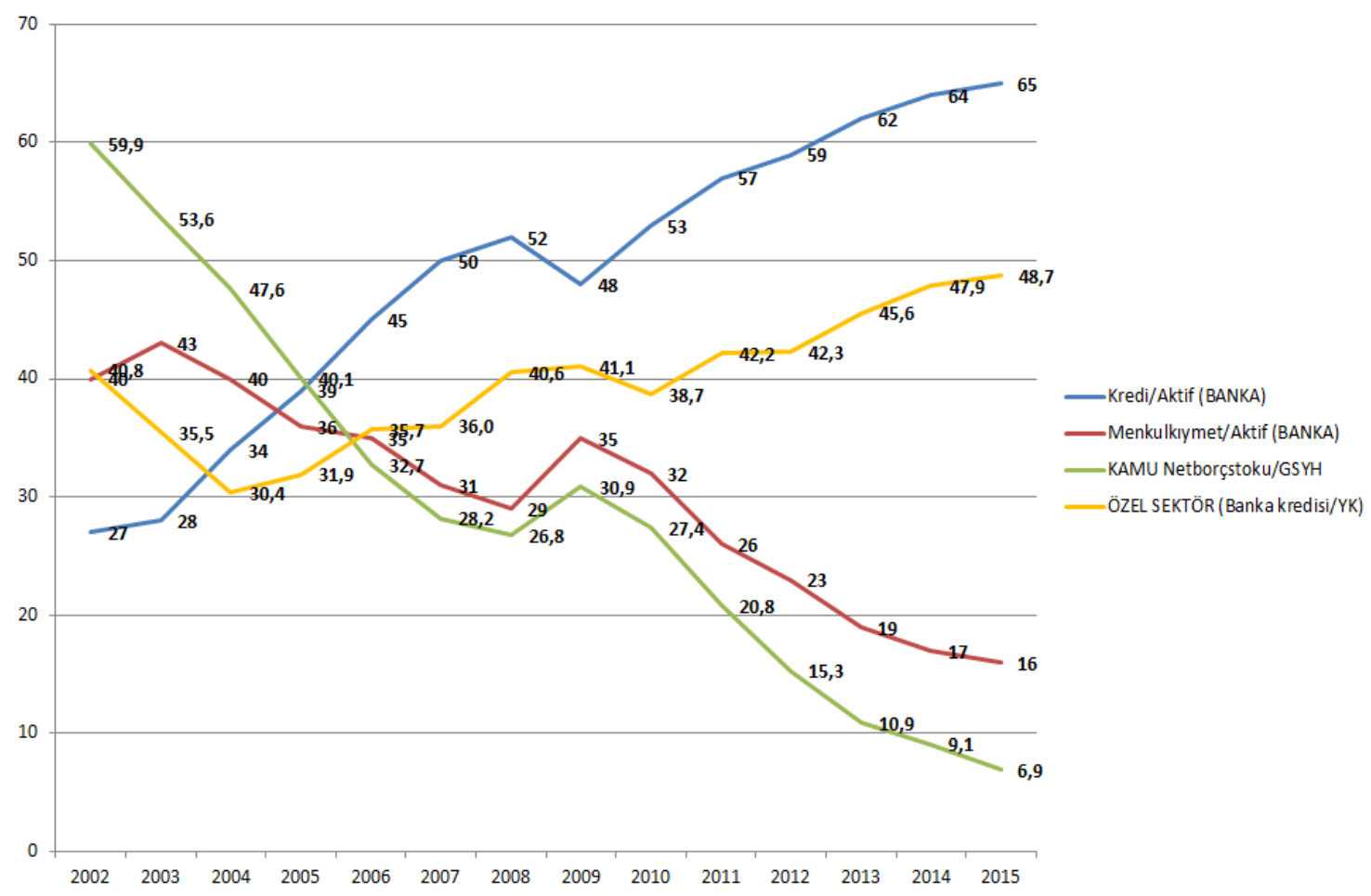

Korelasyon analizinde ortaya çıkan güçlü ilişki grafiksel gösterimde de açıkça görülebilmektedir. "Kredi/aktif" ile "Kamu Net Borç Stoku/GSYH" grafikleri, ortasına bir ayna konulmuş gibi birbirinin simetriğidir. Benzer şekilde banka bilançosundaki "Menkul Kıymet/Aktif" ile özel sektör bilançosundaki "banka kredisi/Yabancı kaynak" arasında da simetrik bir ilişki vardır.

\section{Sonuçlar ve Genel Değerlendirmeler}

2002-2016 yılları arasında bankaların aktif yapısı önemli ölçüde değişmiş olup, menkul kıymet ağırlıklı bilanço yapısından, kredi ağırlıklı bilanço yapısına geçiş sağlanmıştır. Aktif içerisindeki kredilerin pay1 15 yılda \%27'den \%66'ya çıkarken, menkul kıymet payı ise \%40'dan \%15'e düşmüştür. Her ne kadar bilançodaki riskli varlıklarda artış olsa da bankalar menkul kıymet alıp satmak yerine, asıl görevleri olan reel sektörün finansmanına önemli katkı sağlamaya başlamışlardır. Banka bilançolarındaki bu dönüşümün en büyük nedeni, devlet borçlanma ihtiyacının azalması sonucu bankaların devlete borç vererek risksiz kazanç sağlama imkanlarının kaybedilmesidir. Bu nedenle bankalar mevcut kaynaklarını menkul kıymetlere yatırmak yerine, kredi şeklinde reel sektöre aktarmaya başlamışlardır.

Devlet borçlanması ile reel sektör ve banka bilanço yapısı arasında nasıl bir etkileşim olduğunu anlayabilmek amacıyla korelasyon analizi yapılmıştır. 2002-2016 yılları arasında; "Kamu Net Borç Stoku/GSYH" oranının değişimi, özel sektör bilançolarındaki "banka kredileri/yabancı kaynak" oranının değişimi ile Banka bilançolarındaki "Kredi/Aktif" ve "Finansal Varlık/Aktif" oranlarının değişimi arasındaki ilişki incelenmiş ve aralarında çok güçlü bir korelasyon olduğu tespit edilmiştir. Buna göre; Kamu borç stoğunda meydana gelen düşüs, banka bilançolarında "Kredi/Aktif" oranını artırmakta ve "Menkul kıymet/Aktif" oranını azaltmakta, reel sektör bilançolarında ise "banka kredileri/yabancı kaynak" oranını 
artırmaktadır. Dolayısıyla kamu borçlanma ihtiyacının azalması ile birlikte, banka bilançolarında menkul kıymetten kredilere doğru bir dönüşüm sağlanırken, reel sektörün de banka kaynaklarından faydalanma imkanı artmaktadır.

\section{Kaynakça}

Artar O.K. ve Sarıdoğan A.A. (2012). Küresel finansal krizin Türkiye'de bankacılık sektörü mali yapısına etkileri. Marmara Sosyal Araştırmalar Dergisi, Sayı 2, Haziran 2012.

Aslanoğlu, S. (Ed.). (2013). Banka ve Sigorta Muhasebesi. Eskişehir: Anadolu Üniversitesi Yayınlar1.

Aydın, M. F. (2002). Türkiye'de Kamu Kesimi İç Borçlanmasının Bankacılık Sektörü Bilançolarına ve Risklerine Olan Etkileri. TCMB Araştırma Genel Müdürlügü 13 Nolu Çalışma Tebliği.

Babuşcu, Ş. ve Hazar, A. (2013), Bankaların Mali Bünyeleri ile Yasal Düzenlemelerin İlişkisi 5411 Sayılı Bankacılık Kanunu Çerçevesinde Bir Analiz, Muhasebe ve Denetime Bakış Dergisi, 13(39), 79-102.

BDDK, (2007a). Tekdüzen Hesap Planı ve İahnamesi Hakkında Tebliğ, Resmi Gazete, Say1:26415, 26.01.2007.

BDDK, (2007b). Katılım Bankalarınca Uygulanacak Tekdüzen Hesap Planı ve İzahnamesi Hakkında Tebliğ, Resmi Gazete, Sayı: 26415, 26 Ocak 2007.

BIS (Bank For Intenational Settlement), (2018). Structural Changes in banking after the crisis, CGFS Papers no: 60, https://www.bis.org/publ/cgfs60.pdf (19.06.2018).

Blaško, M. \& Sinkey, J. F. (2006). Bank Asset Structure, Real-Estate Lending, and RiskTaking. The Quarterly Review of Economics and Finance, 46(1), 53-81.

Demir, M. ve Sever, E. (2008). Kamu İç Borçlanmasinin Büyüme, Faiz ve Enflasyon Oranı Üzerindeki Etkileri. Elektronik Sosyal Bilimler Dergisi, C.7, S.25 (170-196).

Derya, E.V. (2015). T.C. Başbakanlık Hazine Müsteşarlığı Çalı̧̧ma Raporları (Sayı: 20155/Mart 2015) Türkiye Kamu Net Borç Stoku İstatistikleri Tanım, Kapsam Ve Değerleme Yöntemi, Uluslararası Standartlardan Fark1, Sorunlar Ve Çözüm Önerileri.

Foos, D., Norden, L., \& Weber, M. (2010). Loan growth and riskiness of banks. Journal of Banking \& Finance, 34(12), 2929-2940.

Hazine Müsteşarlığı, (2017). "Kamu Net Borç Stoku İstatistikleri”, https://www.hazine.gov.tr/kamu-finansmani-istatistikleri?type=icon (27.10.2017).

Mengüç, I. T. (2017). Türkiye'de Bankacılık Sektörünün Yapısal Değişimi. Bankacılık ve Sermaye Piyasası Araştırmaları Dergisi, Cilt:1, Sayı:3, 1-14.

Özdemir, Z. (2005). Bilanço Yapısı İtibarıyla Türk Bankacılık Sistemi. Sosyal Siyaset Konferansları Dergisi, Sayı:50, 867-899.

Poyraz, E. (2012). Türk Bankacılık Sektöründe Optimal Kredi Düzeyinin Belirlenmesi. Business and Economics Research Journal, Cilt 3, Say1 2, 41-49.

Schneider, R. A. (2010). Basic Statistics for Social Workers. University Press of America.

Selvigül, A. A. (2012). Güçlü Ekonomiye Geçiş Programı ve Bankacılık Sektörüne Etkisi, İstanbul Teknik Üniversitesi Sosyal Bilimler Enstitüsü, Yüksek Lisans Tezi, İstanbul.

Seyidoğlu, H. (2003). Uluslararası Mali Krizler, IMF Politikaları, Az Gelişmiş Ülkeler, Türkiye ve Dönüşüm Ekonomileri. Doğuş Üniversitesi Dergisi, 4 (2) 2003, 141-156.

Sönmezler, G. (2008). Dışlama Etkisi ve Banka Bilançolarına Yansıması, Trakya Üniversitesi Sosyal Bilimler Dergisi, Cilt.10, Sayı: 1, 1-21.

TBB (Türkiye Bankalar Birliği), (2010). "Bankalarımız 2009”, https://www.tbb.org.tr/Dosyalar/istatistiki_raporlar/Bankalarimiz_Kitabi_/914/Ekler/Bankala rimiz2009-I.bolum.pdf (27.10.2017). 
TBB (Türkiye Bankalar Birliği), (2017a). "Bankalarımız 2016”. Yayın No: 321. https://www.tbb.org.tr/Content/Upload/istatistikiraporlar/ekler/808/Bankalarimiz_2016.pdf (21.12.2017).

TBB (Türkiye Bankalar Birliği), (2017b). "Türkiye’de Bankacılık Sistemi (1958’den İtibaren)",https://www.tbb.org.tr/tr/bankacilik/banka-ve-sektor-bilgileri/istatistiki-raporlar/59 (27.10.2017).

TCMB (Türkiye Cumhuriyet Merkez Bankası), (2017). "Sektör Bilançoları İstatistikleri”, https://www.tcmb.gov.tr/wps/wcm/connect/TR/TCMB+TR/Main+Menu/Istatistikler/Reel+S ektor+Istatistikleri/Sektor+Bilancolari/Sektor+Bilanco+Verileri/.

Tükenmez, N. ve Özdemir, A. (2017). Yirmi Birinci Yüzyılda Türk Bankacıllk Sektörünün Yapısal Değişimi: 2004-2014 Dönemine Bir Bakış. Atatürk Üniversitesi İktisadi ve İdari Bilimler Dergisi, Cilt: 31, Say1: 5. 1127-1148.

Yiğitoğlu, A. İ. (2005). 2001 Krizi Sonrası Dönemde Türkiye Ekonomisinin ve Bankacılık Sektörünün Değerlendirilmesi. Sosyoekonomi, l(1).

5411 Sayılı Bankac1lık Kanunu, (2005). Resmi Gazete, Say1: 25983, 01.11.2005. 